\title{
On the thermal behavior of protein isolated from different legumes investigated by DSC and TGA analyses
}

\author{
Lucia Ricci, ${ }^{a}$ Eleonora Umiltà, ${ }^{\mathrm{b}}$ Maria Cristina Righetti, ${ }^{\mathrm{a}}$ Tiziana Messina, ${ }^{\mathrm{a}}$ Chiara Zurlini, ${ }^{\mathrm{b}}$ Angela \\ Montanari, ${ }^{\mathrm{b}}$ Simona Bronco, ${ }^{\mathrm{a}}$ and Monica Bertoldo ${ }^{\mathrm{a}}$
}

${ }^{a}$ Istituto per i Processi Chimico-Fisici, Sede Secondaria di Pisa, Consiglio Nazionale delle Ricerche CNRIPCF, Area della Ricerca, via G. Moruzzi 1, 56124 Pisa, Italy

${ }^{\mathrm{b}}$ Stazione Sperimentale per 1'Industria delle Conserve Alimentari - SSICA, V.le F.Tanara 31/A, 43100

Parma, Italy

Correspondence to: Monica Bertoldo (E-mail: monica.bertoldo@ipcf.cnr.it)

Keywords: legume proteins, TGA analysis, DSC analysis, purity degree, thermal stability

\section{ABSTRACT}

BACKGROUND: Peas, lentils, faba beans, chickpeas and beans proteins are potentially renewable raw materials for bioplastic production that can be obtained from agriculture waste. Plastics are usually processed under heating and thus the thermal stability is a mandatory requirement for the application. In this study the thermal behaviour of several legume proteins isolates at different purity degree were investigated.

RESULTS: Proteins extracted from legumes exhibited thermal stability maxima for chickpeas, minimum for beans proteins and decreased with the decrease of the protein purity in the $88 \%-30$ $\%$ range. A similar dependence on purity was observed for the glass transition temperature. On the This article has been accepted for publication and undergone full peer review but has not been through the copyediting, typesetting, pagination and proofreading process which may lead to differences between this version and the Version of Record. Please cite this article as doi: $10.1002 /$ jsfa. 9078 
contrary, the denaturation temperature value was found to not depend on sample purity and origin and it was lower than the degradation temperature only in the case of protein samples with purity higher than $60 \%$.

CONCLUSION: Proteins from legumes are suitable to produce thermoplastic biopolymeric materials if isolated at purity higher than $60 \%$. In fact, under this circumstance they can be denaturized without degrading and thus are suitable for extrusion processing.

\section{INTRODUCTION}

The preparation of bio-based plastics by using renewable feedstock is, at present, the most promising solution to petrol consumption.(1) At the end of last century, several products derived from natural resources have become commercially available. Among these, starch-based plastics and poly(lactic acid), which is produced at present from corn, are by far the most common. $(1,2)$ However, with the increase in the demand for these materials the need to move to non-food resources is emerging.(3)

od industry waste represents in this contest a high appealing renewable feedstock.(4) In fact, food is mainly made of polymers such as polysaccharides and proteins that can be both used instead of petrol-based polymers to make plastics.(5) However, while much research has been performed on polysaccharide such as starch, the use of proteins to produce plastic received less attention.(6) On the contrary, their continuous and cohesive matrix forming ability make them attractive for the production of biodegradable plastics in the form of films and sheets.(7) 
Among plants, legumes have the largest protein content: pea, chickpea, bean and lentil contain about $170-300 \mathrm{~g} \mathrm{Kg}^{-1}$ protein with varying concentrations of essential amino acids.(8, 9) In addition to proteins, legumes contain starch, hemicellulose, cellulose and other minor components too. $(8,9)$ To understand the potentiality of proteins for plastic production they must be isolated from the others components. The separation can be performed under dry or wet conditions.(10) The corresponding products are named protein concentrate and protein isolate, respectively. In wet methods, legumes are processed using either alkali or neutral solubilisation, followed by a separation phase that usually is based on isoelectric precipitation or ultrafiltration.(9, 10) Purity degree up to $950 \mathrm{~g} \mathrm{Kg}^{-1}$ can be obtained under wet conditions, while dry methods, even with specific pre- or post- treatments, do not allow protein purity higher than $600 \mathrm{~g} \mathrm{Kg}^{-1}$.(11) In any case, either in dry or wet methods, the actual protein purity depends both on the specific separation procedure and on the starting substrate.(10)

Traditionally, plant proteins have been converted into films by dissolving in solvents or by hydrolysing the proteins using alkaline solutions and later by wet casting to form films.(12) However, melt blending and extrusion process is instead preferred in traditional plastic industry since it is more cost-effective and versatile: extrusion allows the transformation in much more shapes and sizes than casting does. This reason makes extrusion one of the most important polymer processing techniques in use today. Furthermore, extrusion processing does not need any organic solvents and thus it is usually looked as a green and safe technology.

Extrusion requires the formation of a viscose fluid, implying processing above the softening point of the material. However, proteins, because of the wide range of inter-molecular interactions, have low molecular mobility and exhibit softening temperature very high or above the decomposition 
temperature. They are inherently non-thermoplastic, as a consequence.(12) Softening of proteins requires denaturing that means unfolding from the structured native state into a (partially) unstructured state with no or little fixed residual structure.(13) Due to the analogy with the behaviour of semicrystalline polymers, the denaturation temperature $\left(\mathrm{T}_{\mathrm{d}}\right)$ is often called melting temperature, but this does not necessarily imply that proteins completely unfold into a fully amorphous structure as true melting would.(14) Indeed, in its natural environment, a protein is folded into secondary, tertiary, and quaternary structures stabilized through hydrophobic interactions, hydrogen bonding, and electrostatic interactions among amino acid functional groups. Once folded, the structure may be stabilized further, with strong covalent cross-links.(12) It is generally known that the denaturation temperature of proteins depends on the amino acid sequence, the type of chemical additives used and processing method employed. In other words, softening temperature depends on the origin of the proteins but can be affected by physical and/or chemical modification of proteins such as heat treatment and/or blending with plasticizers.(15) Indeed plasticizers are additives that when blended with a polymer decrease its glass transition temperature or in other words make it easier to bend. Among biopolymer plasticizers, water is the most effective.(16) Accordingly, the denaturation temperature of proteins is generally known to decrease Irom 120-200 ${ }^{\circ} \mathrm{C}$ down to $80{ }^{\circ} \mathrm{C}$ by increasing the moisture content from 0 to $200 \mathrm{~g} \mathrm{Kg}^{-1}$.(13) In any case, residual moisture is always present in protein isolates because of their hydrophilic character, even in dry powder when kept in the air. This moisture content has to be considered in the study of the denaturation of proteins in the solid state. Another important temperature value to consider for setting up the processing conditions of polymers is the glass transition temperature, $\mathrm{T}_{\mathrm{g}}$. According to Sochava and co-authors, denaturation and glass transition are essentially based on the same 
physical process: an increase of conformational mobility in the globules.(17) Protein denaturation, or in general a changes of structure, can only occur if the mobility of the material is enough high and $T_{d}>T_{g}$. Extrusion must be performed far above the glass transition temperature so that the macromolecule chain mobility is high enough to allow chain alignment and eventually mixing with other components. $(13,18)$ However, temperature during extrusion cannot be raised to any value but must be kept below a limit value that is dictated by the need to avoid thermal activated reactions, in particular degradation with formation of volatile compounds.(19) It is thus clear that, any protein rich sample to be suitable for extrusion processing must exhibit denaturation temperature enough below the degradation temperature.

In spite to the growing interest in the preparation of bioplastics from legume proteins by melt processing, $(15,16,20-23)$ dipped investigations on the thermal behaviour of legume proteins with low moisture content are still lacking in the literature. Only few studies on DSC analysis of almost dry soy and peas proteins have been reported.(20,24,25) On the contrary, the literature on the thermal behaviour of protein solutions and highly hydrated proteins is quite huge.(26-36) However, the behaviour at different moisture content is very different and the information for the dry state can not be extracted from the one in solution. On the contrary, in order to extend the actual knowledge on protein processing is very important to dip investigate the thermal behaviour of proteins at low moisture content. To this aim, we investigated the thermal behaviour in term of thermal stability, denaturation and glass transition, of several protein isolated from different legumes, namely peas, lentils, faba beans, chickpeas and beans. Furthermore, we investigated how the thermal behaviour is affected by the protein purity.

\section{EXPERIMENTAL}




\section{Materials}

Flour from lentils and chickpeas available on the market and by-products from Borlotti beans, faba beans, lentils and peas, provided by food preservation industries, were used as starting material for proteins extraction.

Phosphate buffers for proteins extraction were prepared by dissolving in ultrapure water suitable amount of one or more salts selected among the following: disodium hydrogen phosphate dodecahydrate (WVR Chemicals, Milano, Italy), potassium dihydrogen phosphate (WVR Chemicals, Milano, Italy), trisodium phosphate (Sigma Aldrich, Milano, Italy), sodium chloride (Sigma Aldrich, Milano, Italy) and potassium chloride (Carlo Erba, Milano, Italy). For proteins precipitation, $37 \%$ hydrochloric acid (VWR Chemicals, Milano, Italy) was used.

2-Amino-2-(hydroxymethyl)-1,3-propanediol hydrochloride (Tris-HCl), 2,2',2",2"'-(ethane-1,2diyldinitrilo)tetraacetic acid (EDTA), sodium dodecyl sulfate (SDS), (2S,3S)-1,4Bis(sulfanyl)butane-2,3-diol（DTT), 4,42(1,1-dioxido-3H-2,1-benzoxathiole-3,3-diyl)bis(2,6dibromophenol) (BBP) were purchased from Sigma Aldrich (Milano, Italy) and used as received to prepare the elution buffer for electrophoresis which was performed on polyacrylamide gel (ExceGel gradient 8-18, GE Healthcare). Bovine serum albumin and Coomassie Blue Brilliant R250 were purchased from Bio-Rad Laboratories, Hercules, CA, USA. Bradford Protein Assay was supplied by Sigma-Aldrich, Milan, Italy.

\section{Proteins extraction}

Extraction of proteins from the legume samples was carried out by a pilot scale version of a procedure previously set up in the lab (FIGURE 1).(37) Briefly legumes by-products were washed in a rotating vegetable washing machine. They were ground and homogenized through a Fryma 
colloidal mill in preparation for extraction with phosphate buffer in a mixer (Labs Food Processing). Legumes flours were directly dispersed and homogenized in extraction buffer. The resulting solid and liquid fractions were separated in Pieralisi decanter and then in an Alfa-Laval solid-liquid separator or by means of a Velp ultrafiltration system. The proteins-rich phase was collected and dried in a Spray-drying Niro Atomizer.

The samples obtained from five different legumes families, namely peas, beans, faba beans, chickpeas and lentils, are listed in Table 1. For each legume, extracts with different purity degrees were obtained, depending on the extraction process scale (laboratory or pilot plant), the buffer type, the separation method and the centrifugation speed etc.

\section{Protein's purity}

The purity degree of protein isolated samples was analysed by Kjeldahl method(38-41) with a Vapodest 5-Gerhardt distiller titrator for nitrogen determination.

\section{SDS-page analysis}

$40 \mathrm{mg}$ of legume proteins was suspended in phosphate buffer at $\mathrm{pH} 7.4\left(50 \mathrm{~g} \mathrm{~L}^{-1}\right)$, stirred at room temperature for $2 \mathrm{~h}$ and then centrifuged. The resulting protein concentration in solutions was termined by the Bradford protein assay at $595 \mathrm{~nm}$ with bovine serum albumin as standard and it

was in the $1.1-0.05 \mathrm{~g} \mathrm{~L}^{-1}$ range. The actual solutions were diluted to $0.229 \mathrm{~g} \mathrm{~L}^{-1}$ with phosphate buffer for all proteins except beans $44 \mathrm{P}$, which has concentration $0.05 \mathrm{~g} \mathrm{~L}^{-1}$. Finally, solutions were mixed with the elution buffer (1:1, v:v) and $10 \mu \mathrm{L}$ was loaded for the analysis by sodium dodecyl sulfate-polyacrylamide gel electrophoresis. Elution buffer consisted of Tris-HCl 10 mM, EDTA 1 $\mathrm{mM}$ pH 8.0, SDS $2.5 \%$, DTT $1 \%$ and BBP $0.01 \%$. The separation was performed on a Multiphor II instrument (Amersham) set at $200 \mathrm{~V}, 20 \mathrm{~mA}$, and $50 \mathrm{~W}$ for $30 \mathrm{~min}$, after which the voltage was 
increased to $600 \mathrm{~V}$ and the current was increased to $50 \mathrm{~mA}$, until the front reached the anode. Staining was carried out with Coomassie Blue Brilliant R250. At the end of the run the gels were analysed with a Chemidoc system and Quantity One software (Bio-Rad).(42)

\section{Conditioning of protein isolates samples to $15 \%$ of moisture content}

$100 \mathrm{mg}$ of protein powder was placed in an air-tight container at $\sim 50 \%$ relative humidity atmosphere (which was achieved with saturated solution of calcium nitrate tetrahydrate) at room temperature up to $150 \mathrm{~g} \mathrm{Kg}^{-1}$ of moisture content (15\%). Sample weight was checked daily with an analytic balance $( \pm 0.1 \mathrm{mg})$. The initial moisture content of samples was determined by the first weight loss step in the TGA analysis (above $180{ }^{\circ} \mathrm{C}$ ) and any observed weight increase was assumed as moisture uptake. The target moisture content $\left(150 \mathrm{~g} \mathrm{Kg}^{-1}\right)$ was selected as just little larger than the largest value $\left(133 \pm 10 \mathrm{~g} \mathrm{Kg}^{-1}\right.$ for Peas_30P) that was observed among the investigated legume protein samples in equilibrium with atmosphere. Values further larger were avoided to prevent large overpressure into the sealed DSC pan during analyses that may result in pan failure with moisture lose.

\section{FT-IR spectroscopy}

w. frared spectra were recorded with a Jasco FT/IR-6200 spectrometer equipped with a Pike Technologies MIRacle ${ }^{\mathrm{TM}}$ Single Reflection Horizontal attenuated total reflectance ATR accessory mounting a germanium crystal. Background and sample spectra were collected by accumulating 64 scans from 4000 to $650 \mathrm{~cm}^{-1}$. 


\section{Differential Scanning Calorimetry (DSC)}

Denaturation of proteins is usually an irreversible thermal activated process and can be detected by DSC analyses in the first heating scan. On the contrary, glass transition is reversible and can be detected by DSC analysis at any heating or cooling scan, once the protein has been brought into a disordered arrangement. Therefore, the value of glass transition temperature of proteins must be extracted from the second heating scan, after the proteins have being denaturised and any aging phenomena has being erased. Analysis was carried out on proteins all conditioned with $15 \%$ moisture content in hermetic closed pan to avoid moisture lose. Moisture is known to widely affect transition temperature, kinetic and reversibility of transitions, as well as the thermal capacity.(17, 19)

DSC analyses of proteins are usually performed at relatively low heating speed, $5^{\circ} \mathrm{C} / \mathrm{min}$ or 10 ${ }^{\circ} \mathrm{C} / \mathrm{min}$. However, the specific heat capacity $\left(\mathrm{C}_{\mathrm{p}}\right)$ jump at the glass transition of plant proteins is usually weak.(43) Increasing the heating speed is known to improve $C_{p}$ jump detectability. For this reason, analyses were carried out at $20^{\circ} \mathrm{C} / \mathrm{min}$.

Glass transition temperature $\left(\mathrm{T}_{\mathrm{g}}\right)$ was taken as temperature at the inflection point in the second ating step, that is after protein denaturation, which occurred in the first step. $T_{d}$ was taken as temperature at the maximum peak.

Calorimetric measurements were performed by using a Perkin-Elmer differential scanning calorimeter DSC 8500 equipped with an Intracooler III as refrigerating system. The instrument was calibrated in temperature and in energy with high purity standards (indium, naphthalene, and cyclohexane), according to the procedure for standard DSC.(44) Samples of about $10 \mathrm{mg}$ were 
contained in sealed aluminium DSC pans. Dry nitrogen was used as purge gas at a rate of $30 \mathrm{ml}$ $\min ^{-1}$. To obtain $C_{p}$ data, measurements were made by using scans performed for empty pans under identical conditions, including the sample pan mass which was within $\pm 0.05 \mathrm{mg}$. The baselinecorrected heat flow rate curves were converted into $C_{p}$ (in $\mathrm{J} \mathrm{g}^{-1} \mathrm{~K}^{-1}$ ) after calibration of the heat flow rate by using sapphire as standard material.

\section{Thermogravimetric Analysis (TGA)}

Thermogravimetric analyses were carried out from $30{ }^{\circ} \mathrm{C}$ to $900{ }^{\circ} \mathrm{C}$ under nitrogen atmosphere $(200$ $\mathrm{ml} / \mathrm{min}$ ) in a Seiko thermogravimetric analyser SII TG/DTA 7200 EXSTAR. Samples (5-10 mg) were analysed in alumina pan at $10^{\circ} \mathrm{C} / \mathrm{min}$ as heating rate.

The temperature at which proteins start to degrade $\left(\mathrm{T}_{\mathrm{dg}}\right)$ was assumed as the onset temperature of the second weight loss step, the first one being assigned to moisture loss.

\section{RESULTS}

\section{SDS page analysis}

Proteins that have been extracted from several legumes under different condition resulted in different purity degree (see Table 1) and were analysed by electrophoresis to investigate possible differences in their protein composition. For analysis, samples were solubilized in phosphate buffer at $\mathrm{pH}$ 7.4. This medium was selected because it is compatible with the running buffer and it is similar to the buffer systems used for extracting proteins from legumes. The runs in the SDS page showed several bands with different intensity for all samples (Table 2) thus indicating that all samples are composed by several proteins or protein fragments at different molecular weight. 
The most significant band present in all samples is the band at $70 \mathrm{kDa}$, associated with convicilline. A second well marked band common to all samples is positioned in the area of $32 \mathrm{kDa}$. It was not attributed but it can be assigned to a protein fragment. In all legume samples, except in beans, there is a fragment at $37-38 \mathrm{kDa}$ that is split into a second fragment at $40 \mathrm{kDa}$ in faba beans and lentils. These bands can be assigned to the acid fraction of legumine. All samples exhibited very weak bands at low molecular weight, among which the better detectable is at $15-16 \mathrm{kDa}$ and it can be assigned to ${ }^{3}$ vicilline.

The samples of Lentils_75P and Faba beans_88P gave the highest number of bands among the analysed samples. These bands were mostly in the 32-70 kDa regions for lentils and 15-24 kDa and 32-55 $\mathrm{kDa}$ for faba beans. In both cases, the bands were narrow thus suggesting the occurring of fragmentation of the original protein, most likely vicilline.

\section{Infrared spectroscopy analyses of protein isolates samples}

Infrared spectroscopy was exploited to investigate possible compositional differences among the protein isolate samples used in this study. SDS page provided information only on proteins and only on the fraction soluble under the analysis condition. On the contrary, FT-IR was used to investigate the whole sample. As expected, FT-IR analysis showed typical absorption bands of proteins: amide I at $1640 \mathrm{~cm}^{-1}$ due to the $\mathrm{C}=\mathrm{O}$ stretching vibrations, amide II at $1540 \mathrm{~cm}^{-1}$ that is typically attributed to the coupling of the N-H in-plane bending and C-N stretching modes and amide III band in 1350$1190 \mathrm{~cm}^{-1}$ region due to the $\mathrm{C}-\mathrm{N}$ stretching coupled to the in-plane N-H bending mode (FIGURE 2). $(45,46)$ Additional bands at $1745 \mathrm{~cm}^{-1}$ and $1160 \mathrm{~cm}^{-1}$ were observed in chickpeas at high purity, as well as in peas, even if less intense (FIGURE 2). Similar absorptions have been reported in others chickpeas proteins(47-49) and were attributed to ester functional group of pectin residua in 
the sample. Typical polysaccharide bands in the region between $1250-1000 \mathrm{~cm}^{-1}$ due to $\mathrm{C}-\mathrm{C}$ and $\mathrm{C}-$ O stretching in sugar rings $(47,48)$ were also observed in the spectra of samples at low purity (FIGURE 2B).

The comparison among the infrared spectra of peas samples at different purity (FIGURE 3) clearly evidences an intensity increase in the band at $1078 \mathrm{~cm}^{-1}$ with decrease in purity. This result indicates an inverse correlation between sample purity and polysaccharide residue in the sample.

\section{Thermal stability of protein isolated from different legumes}

Thermogravimetric analysis was exploited to study the thermal stability of the protein isolates samples that were obtain from different legumes and two well-separated weight loss steps were observed in all recorded thermograms (FIGURE 4). The step starting at the beginning of the analysis and finishing at about $150{ }^{\circ} \mathrm{C}$ was assigned to the loss of humidity. The height of this step gave moisture content in the range between 80 and $135 \mathrm{~g} \mathrm{Kg}^{-1}$ for peas, lentils and beans samples, while chickpeas and faba beans had 30 and $60 \mathrm{~g} \mathrm{Kg}^{-1}$, respectively. The lower moisture content in the two latter samples than in the formers indicates a lower hydrophilic character of the latter two samples. The second step corresponds to the volatilization of protein fragments that are generated oy thermal-activated reactions (decomposition) and its onset temperature is thus assumed as upper thermal stability limit $\left(\mathrm{T}_{\mathrm{dg}}\right)$ (Table 1$)$. The temperature value of this limit was found to range in between $178^{\circ} \mathrm{C}$ and $288^{\circ} \mathrm{C}$, strongly depending on the proteins origin and purity.

The comparison among the derivative plot of the thermograms for different proteins, all at relatively high purity (e $700 \mathrm{~g} \mathrm{Kg}^{-1}$ ) (inset in FIGURE 4A) evidences a main degradation process with a maximum peak in the derivative plot at $330{ }^{\circ} \mathrm{C}$ for all investigated legumes. Chickpeas exhibits also 
a second peak at $380{ }^{\circ} \mathrm{C}$, which is not present in the other samples, while a minor peak with maximum at around $220^{\circ} \mathrm{C}$ was detected in lentils. Legume proteins with purity in the $450-550 \mathrm{~g}$ $\mathrm{Kg}^{-1}$ range (FIGURE 4B), showed a main peak shifted a lower temperature $\left(305-320{ }^{\circ} \mathrm{C}\right)$ with respect to the peak observed in the samples with $\mathrm{P}$ e $700 \mathrm{~g} \mathrm{Kg}^{-1}$. In addition, other minor peaks are also present. The difference among the thermograms of samples at different purity can be due to the degradation of the non-protein components present in the samples. However, the shift of the main peak indicates that there are also some interactions between the proteins and the other components affecting the thermal behaviour of the proteins.

Proteins with comparable purity but from different legumes seem to differ in the residue at $800{ }^{\circ} \mathrm{C}$ value, also: faba beans and chickpeas displaying the lowest and highest value, respectively, with intermediate values for peas, lentils and beans (FIGURE $4 \mathrm{~A}$ and $4 \mathrm{~B}$ ). The residuum at $800^{\circ} \mathrm{C}$ was observed to depend on the sample purity also (FIGURE 4A vs. 4B).

In order to deeper investigate the effect of sample purity, several samples from peas, lentils and beans at different purity were compared (FIGURE 5). In the case of peas, the increase in purity resulted in a clear increase in the thermal stability (Table 1) and a decrease in the final residue at $800{ }^{\circ} \mathrm{C}$ (FIGURE 5A). On the contrary, the purity degree was found to not affect the moisture content: only sample Peas_30P (the peas protein sample with lowest purity degree) showed an amount of moisture higher than that of the other samples. Similar to peas, lentils samples showed an inverse correlation between purity and residuum at $800{ }^{\circ} \mathrm{C}$ values, while the effect on the thermal stability (Table 1) was smaller than that observed for peas. Indeed, Lentils_45P and Lentils_60P exhibited similar thermal stability, even if their purity degree is very different. Furthermore, in the temperature range $200-300{ }^{\circ} \mathrm{C}$ purer proteins degraded more than less pure ones, which is the 
opposite of what was observed for peas. Like peas, in the case of beans proteins, the thermal stability increased with the purity degree. However, unlike the other investigated legumes, the residuum at $800^{\circ} \mathrm{C}$ was quite unaffected by the purity degree.

\section{DSC analysis of protein isolates samples}

DSC analyses of all investigated protein samples with $150 \mathrm{~g} \mathrm{Kg}^{-1}$ of moisture showed the presence of a denaturation peak at very high temperature $\left(T_{d}\right)$ : the maximum peak was found in a small range between 195 and $210{ }^{\circ} \mathrm{C}$ (FIGURE 6) without any correlation with purity or protein origin. The most obvious differences are highlighted on the " $\mathrm{H}_{\mathrm{d}}$ calculated from the area of denaturation peak. The enthalpy change reflects the extent of ordered structure of the globulins as the transition from native to denatured state took place. As for the peak position, there is not any correlation between purity degree and " $\mathrm{H}_{\mathrm{d}}$. It seems, instead, in the case of peas proteins, that there is an inverse correlation between $T_{d}$ and " $H_{d}$ (FIGURE 7), even if not linear. Sample with higher $T_{d}$ seems to have the lower value of " $\mathrm{H}_{\mathrm{d}}$ and vice versa.

After being heat denaturised in the first heating step of analysis, proteins exhibit a typical glass transition jump in the second heating step of the DSC analysis (FIGURE 8). The observed values ranges between $92{ }^{\circ} \mathrm{C}$ and $173{ }^{\circ} \mathrm{C}$ (Table 1), depending on both proteins origin and purity. In particular, an increase in $\mathrm{T}_{\mathrm{g}}$ values with the increase in purity degree was observed: Peas_30P (peas proteins with the lowest purity) shows a $\mathrm{T}_{\mathrm{g}}$ at about $92{ }^{\circ} \mathrm{C}$, while Peas_80P (peas proteins with the highest purity) has the highest $\mathrm{T}_{\mathrm{g}}$ values among peas samples (about $144{ }^{\circ} \mathrm{C}$ ). 


\section{DISCUSSION}

Thermal, spectroscopic and electrophoretic results obtained by TGA, DSC, ATR-FTIR and SDSpage analyses have been correlated with the purity degree to verify the possible dependence among these data. In figure 9A the correlation plots for peas proteins are reported showing that the denaturation temperature is almost unaffected by the purity degree being around $200{ }^{\circ} \mathrm{C}$ for all investigated peas samples. On the contrary, the degradation temperature increases with the purity degree. By comparing the degradation and denaturation temperatures it can be seen that: the degradation is lower at low purity degrees, higher at purity degrees equal to or higher than $700 \mathrm{~g}$ $\mathrm{Kg}^{-1}$ and similar at $500 \mathrm{~g} \mathrm{Kg}^{-1}$ purity degree. This means that peas proteins with purity degree of $500 \mathrm{~g} \mathrm{Kg}^{-1}$ or lower cannot be denaturized at low moisture content $\left(150 \mathrm{~g} \mathrm{Kg}^{-1}\right)$ without degrading, or in other words, they cannot be processed in the dry state, except in the presence of additives able to promote denaturation or thermal stability.(13) On the contrary, peas proteins with purity higher than $700 \mathrm{~g} \mathrm{Kg}^{-1}$ can be processed at low moisture content. Furthermore, increasing the purity degree the thermal window for processing, which is the temperature range between the denaturation and degradation temperature, becomes progressively larger.

In order to investigate the molecular origin of the highest thermal stability of the purest peas samples the possible correlations between purity degree and compositional information, which were recovered by SDS page, FT-IR and TGA analysis, were analysed. Only two values were found to correlate with the purity degree: the intensity of the polysaccharide band and the TGA residuum at $800{ }^{\circ} \mathrm{C}$ both showed an inverse correlation (FIGURE 9A). This result suggests that peas proteins at low purity degree contain some polysaccharide co-products having lower thermal stability and giving higher residuum at $800{ }^{\circ} \mathrm{C}$ than proteins. Since no correlation was found between protein 
molecular weight and thermal stability, it cannot be invoked for explaining the different thermal stability. Polysaccharide co-products are thus tentatively assumed to be responsible for the low thermal stability of peas samples at low purity.

It is interesting to observe that all investigated legume proteins different from peas exhibited degradation temperature higher than the denaturation temperature at any investigated purity degree. This means that all these proteins can be processed without significant degradation. Furthermore, it can be indicated that the low thermal stability of peas proteins at low purity is due to peculiarities of these samples such as the presence of specific co-products that are not present in the other samples or to some interaction among the co-products and the proteins able to affect the thermal stability of these components. Indeed, the comparison among the FT-IR spectra of the proteins of low purity degree, namely Peas_50P, Beans_55P and Lentils_45P, did not showed significant differences in the intensity and shape of the polysaccharide band in the three samples, thus indicating no significant difference in the polysaccharide co-product profile. Therefore, differences in the specific interaction between the co-products and proteins in the samples are suggested to be responsible for the low thermal stability in peas proteins at low purity.

Going further in the analysis of the thermal behaviour, the glass transition temperature was ooserved to exhibit a dependence on purity degree similar to the degradation temperature in the case of peas proteins: the two temperatures differ in almost 100 degrees, constantly. A similar difference was observed for the other legume proteins at any purity degree thus indicating the existence of univocal physical process not depending on sample composition or molecular organization. On the contrary, no correlation was observed between the glass transition and the denaturation temperature, which values at least seem to converge at high purity degree, in the case of peas proteins. The 
correlation between glass transition and degradation temperatures, even if the former is related to protein samples with $150 \mathrm{~g} \mathrm{Kg}^{-1}$ of moisture and the latter to dry samples, suggests a common explanation for the two effects. Under the hypothesis that some specific interaction between polysaccharide co-products are responsible for the reduced thermal stability, these are invoked to explain also the variation in the glass transition temperature. Indeed, the principles of denaturation and glass transition of globular proteins were combined at first by Sochova, who stated that they are essentially based on the same physical process: an increase of conformational mobility in the globules. $(17,25)$ In the case of pure proteins, the two values are usually assumed to correspond at zero moisture content and progressively diverge by increasing the protein plasticisation.(13) This behaviour is similar to the one observed here for thermal stability and the glass transition of peas proteins at decreasing purity degree, that suggests a plasticisation role of co-products present inside the proteins sample at low purity. However, unlikely others plasticizers such as water, polysaccharide co-products have not any effect on the denaturation temperature.(13) In any case, the presence of a single $C_{p}$ jump in the second scan of the DSC thermogram, even if large, clearly indicates a mixing at molecular level between proteins and co-products, likely in a solid solution, thus supporting the plasticization hypothesis.

the comparison among different legumes with comparable purity level (FIGURE 9B), namely equal or higher than $700 \mathrm{~g} \mathrm{Kg}^{-1}$, showed that the glass transition temperature is higher in the legume proteins different from peas; the denaturation temperature is slightly lower and the degradation temperature is comparable, except for chickpeas, for which it is higher (FIGURE 9B). In any case, the differences are small in absolute value (Table 1) and it can be explain with the differences in protein composition and/or differences in the co-products present into the samples, as indicated by 
the intensity of the polysaccharide band from ATR spectroscopy and the residuum at $800{ }^{\circ} \mathrm{C}$. These latter values, even if scattered, are higher at comparable purity degree in legumes others than peas. Therefore, a different interaction between co-products and proteins and a different plasticization effect of co-products can be invoked to explain the minor difference in the thermal behaviour of the different legume proteins.

\section{CONCLUSIONS}

The analysis of the thermal behaviour of proteins at different purity from different legumes showed a clear correlation between purity degree and thermal stability, which showed a direct correlation. On the contrary, less clear is the effect on the thermal stability of the legume from which proteins have been isolated.

Proteins with purity degree higher than $700 \mathrm{~g} \mathrm{Kg}^{-1}$ exhibited denaturation temperature at $150 \mathrm{~g} \mathrm{Kg}^{-1}$ of moisture content lower than their degradation temperature thus indicating that, at least at this moisture content, there is a temperature window inside which these proteins can be heat processed. The temperature window between $200{ }^{\circ} \mathrm{C}$ and $240{ }^{\circ} \mathrm{C}$ is suitable, for instance, for blending the purest proteins with thermoplastic biodegradable polymers such as poly(lactic acid) or poly(butylene succinate), which melt at about $160{ }^{\circ} \mathrm{C}$ and $115{ }^{\circ} \mathrm{C}$, respectively. The results of the present investigation thus open the possibility to prepare thermoplastic fully biodegradable plastics by using legume proteins as component. 


\section{ACKNOWLEDGES}

The research leading to these results has received funding from the European Union's Seventh Framework Programme for research, technological development and demonstration under grant agreement $n^{\circ}$ [315241] Leguval project.

The authors would like to thank Dr. Gianpiero Barbieri (SSICA) who kindly performed the SDS analysis on protein samples. 


\section{REFERENCES}

1. Christensen CH, Rass-Hansen J, Marsden CC, Taarning E and Egeblad K. The renewable chemicals industry. ChemSusChem. 2008; 1(4): 283-289. https://doi.org/10.1002/cssc.200700168. 2. Ravenstijn JTJ. The State-of-the-art on Bioplastics: Products, Markets, Trends, and Technologies. Lüdenscheid: Polymedia Publisher GmbH, 2010.

3. Yang S-T and Yu M. Integrated Biorefinery for Sustainable Production of Fuels, Chemicals, and Polymers. In: Yang S-T, El-Ensashy H, Thongchul N (eds). Bioprocessing Technologies in Biorefinery for Sustainable Production of Fuels, Chemicals, and Polymers. Hoboken, New Jersey: John Wiley \& Sons, Inc., 2013; 1-26.

4. Matharu AS, de Melo EM and Houghton JA. Opportunity for high value-added chemicals from food supply chain wastes. Bioresour. Technol. 2016; 215: 123-130. http://dx.doi.org/10.1016/j.biortech.2016.03.039.

5. Song Y and Zheng Q. Ecomaterials Based on Food Proteins and Polysaccharides. Polym. Rev. 2014; 54(3): 514-571. https://doi.org/10.1080/15583724.2014.887097.

6. Tuck CO, Pérez E, Horváth IT, Sheldon RA and Poliakoff M. Valorization of Biomass: Deriving More Value from Waste. Science. 2012; 337(6095): 695-699. https://doi.org/10.1126/science.1218930.

7. Mekonnen T, Mussone P, Khalil H and Bressler D. Progress in bio-based plastics and plasticizing modifications. J. Mater. Chem. A. 2013; 1(43): 13379. https://doi.org/10.1039/c3ta12555f.

8. Sathe SK, Deshpande SS, Salunkhe DK and Rackis JJ. Dry beans of phaseolus. A review. Part 1. Chemical composition: Proteins. Crit. Rev. Food. Sci. 1984; 20(1): 1-46. https://doi.org/10.1080/10408398409527382.

9. Day L. Proteins from land plants - Potential resources for human nutrition and food security. Trends Food Sci. Technol. 2013; 32(1): 25-42.

http://dx.doi.org/10.1016/j.tifs.2013.05.005.

10. Gueguen J. Legume seed protein extraction, processing, and end product characteristics. Plant Food. Hum. Nutr. 1983; 32(3): 267-303. https://doi.org/10.1007/bf01091191.

11. Pelgrom PJM, Wang J, Boom RM and Schutyser MAI. Pre- and post-treatment enhance the protein enrichment from milling and air classification of legumes. J. Food Eng. 2015; 155: 53-61. https://doi.org/10.1016/j.jfoodeng.2015.01.005.

14. Verbeek CJR and van den Berg LE. Extrusion Processing and Properties of Protein-Based Thermoplastics. Macromol. Mater. Eng. 2010; 295(1): 10-21. https://doi.org/10.1002/mame.200900167.

13. De Graaf LA. Denaturation of proteins from a non-food perspective. J. Biotechnol. 2000; 79(3): 299-306. http://dx.doi.org/10.1016/S0168-1656(00)00245-5.

14. Bier JM, Verbeek CJR and Lay MC. Thermal Transitions and Structural Relaxations in Protein-Based Thermoplastics. Macromol. Mater. Eng. 2014; 299(5): 524-539. https://doi.org/10.1002/mame.201300248.

15. Reddy N and Yang Y. Thermoplastic films from plant proteins. J. Appl. Polym. Sci. 2013; 130(2): 729-738. https://doi.org/10.1002/app.39481. 
16. Hernandez-Izquierdo VM and Krochta JM. Thermoplastic processing of proteins for film formation--a review. J. Food Sci. Tech. 2008; 73(2): R30-39. https://doi.org/10.1111/j.17503841.2007.00636.x.

17. Sochava IV and Smirnova OI. Heat capacity of hydrated and dehydrated globular proteins. Denaturation increment of heat capacity. Food Hydrocolloid. 1993; 6(6): 513-524. http://dx.doi.org/10.1016/S0268-005X(09)80075-1.

18. Kokini JL, Cocero AM, Madeka $\mathrm{H}$ and de Graaf E. The development of state diagrams for cereal proteins. Trends Food Sci. Technol. 1994; 5(9): 281-288. http://dx.doi.org/10.1016/09242244(94)90136-8.

19. Sablani SS, Syamaladevi RM and Swanson BG. A Review of Methods, Data and Applications of State Diagrams of Food Systems. Food Eng. Rev. 2010; 2(3): 168-203. https://doi.org/10.1007/s12393-010-9020-6.

20. Perez V, Felix M, Romero A and Guerrero A. Characterization of pea protein-based bioplastics processed by injection moulding. Food Bioprod. Process. 2016; 97: 100-108. http://dx.doi.org/10.1016/j.fbp.2015.12.004.

21. Kluver E and Meyer M. Thermoplastic Processing, Rheology, and Extrudate Properties of Wheat, Soy, and Pea Proteins. Polym. Eng. Sci. 2015; 55(8): 1912-1919. https://doi.org/10.1002/pen.24032.

22. Felix M, Perez-Puyana V, Romero A and Guerrero A. Production and Characterization of Bioplastics Obtained by Injection Moulding of Various Protein Systems. J. Polym. Environ. 2017; 25(1): 91-100. https://doi.org/10.1007/s10924-016-0790-7.

23. Reddy N. A review on completely biodegradable composites developed using soy-based matrices. J. Reinf. Plast. Comp. 2015; 34(18): 1457-1475. https://doi.org/10.1177/0731684415573815.

24. Schmidt V, Giacomelli C and Soldi V. Thermal stability of films formed by soy protein isolate-sodium dodecyl sulfate. Polym. Degrad. Stabil. 2005; 87(1): 25-31. http://dx.doi.org/10.1016/j.polymdegradstab.2004.07.003.

25. Sochava IV. Heat capacity and thermodynamic characteristics of denaturation and glass transition of hydrated and anhydrous proteins. Biophys. Chem. 1997; 69(1): 31-41. http://dx.doi.org/10.1016/S0301-4622(97)00072-0.

26. Mession JL, Sok N, Assifaoui A and Saurel R. Thermal denaturation of pea globulins (Pisum sativum L.) - Molecular interactions leading to heat-induced protein aggregation. J. Agric. rood Chem. 2013; 61(6): 1196-1204. https://doi.org/10.1021/jf303739n.

27. Sirtori E, Isak I, Resta D, Boschin G and Arnoldi A. Mechanical and thermal processing effects on protein integrity and peptide fingerprint of pea protein isolate. Food Chem. 2012; 134(1): 113-121. https://doi.org/10.1016/j.foodchem.2012.02.073.

28. Rui X, Boye JI, Ribereau S, Simpson BK and Prasher SO. Comparative study of the composition and thermal properties of protein isolates prepared from nine Phaseolus vulgaris legume varieties. Food Res. Int. 2011; 44(8): 2497-2504. https://doi.org/10.1016/j.foodres.2011.01.008.

29. Ahmed J, Varshney SK and Ramaswamy HS. Effect of high pressure treatment on thermal and rheological properties of lentil flour slurry. LWT-Food Sci. Technol. 2009; 42(9): 1538-1544. https://doi.org/10.1016/j.lwt.2009.05.002. 
30. Tang $\mathrm{CH}$. Thermal denaturation and gelation of vicilin-rich protein isolates from three Phaseolus legumes: A comparative study. LWT-Food Sci. Technol. 2008; 41(8): 1380-1388. https://doi.org/10.1016/j.lwt.2007.08.025.

31. Ryan M, McEvoy E, Duignan S, Crowley C, Fenelon M, O'Callaghan DM and FitzGerald RJ. Thermal stability of soy protein isolate and hydrolysate ingredients. Food Chem. 2008; 108(2): 503-510. https://doi.org/10.1016/j.foodchem.2007.11.001.

32. Tang $\mathrm{CH}$, Choi SM and Ma CY. Study of thermal properties and heat-induced denaturation and aggregation of soy proteins by modulated differential scanning calorimetry. Int. J. Bio.1 Macromol. 2007; 40(2): 96-104. https://doi.org/10.1016/j.ijbiomac.2006.06.013.

33. Emami S, Tabil LG and Tyler RT. Thermal properties of chickpea flour, isolated chickpea starch, and isolated chickpea protein. Trans. ASABE. 2007; 50(2): 597-604. https://doi.org/10.13031/2013.22648.

34. Henshaw FO, McWatters KH, Akingbala JO and Chinnan MS. Thermal properties of cowpea flour: a study by differential scanning calorimetry. Nahrung. 2003; 47(3): 161-165. https://doi.org/10.1002/food.200390038.

35. Meng GT and Ma CY. Thermal properties of Phasoleus angularis (red bean) globulin. Food Chem. 2001; 73: 453. https://doi.org/10.1016/S0308-8146(00)00329-0.

36. Sousa IMN, Mitchell JR, Ledward DA, Hill SE and daCosta MLB. Differential scanning calorimetry of lupin and soy proteins. Z Lebensm. Unters. Forsch. A-Food Res. Technol. 1995; 201(6): 566-569. https://doi.org/10.1007/Bf01201587.

37. Montanari A and Zurlini C, inventors; Stazione sperimentale per l'industria delle conserve alimentari, Parma (PR), assignee. Biopolimero da scarti dell'industria alimentare. Italia patent 0001399500. 201319 April 2013.

38. Bradstreet RB. Kjeldahl Method for Organic Nitrogen. Anal. Chem. 1954; 26(1): 185-187. https://doi.org/10.1021/ac60085a028.

39. Pomeranz Y and Meloan CE. Food Analysis: Theory and Practice. Westport, Connecticut: AVI Publishing Company, Inc., 1978.

40. Jones Jr J. Kjeldahl method for nitrogen determination. Athens, Georgia: Micro-Macro Publishing, Inc., 1991.

41. Cunniff P. Official methods of analysis of the AOAC International. Washington (D.C.): AOAC International, 1995.

42. Claeys E, Uytterhaegen L, Buts B and Demeyer D. Quantification of beef myofibrillar proteins by SDS-PAGE. Meat Sci. 1995; 39(2): 177-193. http://dx.doi.org/10.1016/03091740(94)P1819-H.

43. Rouilly A, Orliac O, Silvestre F and Rigal L. DSC study on the thermal properties of sunflower proteins according to their water content. Polymer. 2001; 42(26): 10111-10117. https://doi.org/10.1016/s0032-3861(01)00555-9.

44. Sarge SM, Hemminger W, Gmelin E, Höhne GWH, Cammenga HK and Eysel W. Metrologically based procedures for the temperature, heat and heat flow rate calibration of DSC. J. Therm. Anal. 1997; 49(2): 1125-1134. https://doi.org/10.1007/bf01996802.

45. Bramanti E and Benedetti E. Determination of the secondary structure of isomeric forms of human serum albumin by a particular frequency deconvolution procedure applied to Fourier transform IR analysis. Biopolymers. 1996; 38(5): 639-653. https://doi.org/10.1002/(SICI)10970282(199605)38:5<639::AID-BIP8>3.0.CO;2-T 
46. Carbonaro M and Nucara A. Secondary structure of food proteins by Fourier transform spectroscopy in the mid-infrared region. Amino Acids. 2010; 38(3): 679-690.

https://doi.org/10.1007/s00726-009-0274-3.

47. Amir RM, Anjum FM, Khan MI, Khan MR, Pasha I and Nadeem M. Application of Fourier transform infrared (FTIR) spectroscopy for the identification of wheat varieties. J. Food Sci. Tech. 2013; 50(5): 1018-1023. https://doi.org/10.1007/s13197-011-0424-y.

48. Kizil R, Irudayaraj J and Seetharaman K. Characterization of irradiated starches by using FT-Raman and FTIR spectroscopy. J. Agric. Food Chem. 2002; 50(14): 3912-3918. https://doi.org/10.1021/Jf011652p.

49. Chatjigakis AK, Pappas C, Proxenia N, Kalantzi O, Rodis P and Polissiou M. FT-IR spectroscopic determination of the degree of esterification of cell wall pectins from stored peaches and correlation to textural changes. Carbohyd. Polym. 1998; 37(4): 395-408.

https://doi.org/10.1016/S0144-8617(98)00057-5. 


\section{Figure Captions}

FIGURE 1. Flow-sheet of the basic extraction procedure applied at pilot scale

FIGURE 2. Comparison among ATR-FTIR spectra of proteins isolated from different legumes. Samples with (A) high purity ( $\mathrm{P}$ e $700 \mathrm{~g} \mathrm{Kg}^{-1}$ ) and (B) medium purity ( $450 \mathrm{~g} \mathrm{Kg}^{-1} \mathrm{~d}$ P d $550 \mathrm{~g} \mathrm{Kg}^{-}$ $\left.{ }^{1}\right)$. For comparison purpose, spectra were normalized with respect to the band at $1640 \mathrm{~cm}^{-1}$.

FIGURE 3. Comparison among ATR-FTIR spectra of peas proteins with different purity degree. For comparison purpose, spectra were normalized with respect to the band at $1640 \mathrm{~cm}^{-1}$.

FIGURE 4. Comparison of TGA thermograms of protein isolated from different legumes. (A) samples with high purity (P e $700 \mathrm{~g} \mathrm{Kg}^{-1}$ ) (B), samples with medium purity (450 $\mathrm{g} \mathrm{Kg}^{-1} \mathrm{~d} \mathrm{P} \mathrm{d} 550 \mathrm{~g}$ $\left.\mathrm{Kg}^{-1}\right)$.

FIGURE 5. Comparison among TGA thermograms of proteins with different purity degrees: (A) peas, (B), lentils, (C) beans.

FIGURE 6. DSC thermograms of peas proteins with different purity degrees (first heating).

FIGURE 7. Correlation between $T_{d}$ and " $H_{d}$.

FIGURE 8. Comparison among the second heating steps of DSC thermograms of peas proteins with different purity degrees.

FIGURE 9. Correlation between thermal properties and purity degree of extracted peas proteins (A) and proteins at high purity from different legumes (B). Lines on graph B are guides for eyes. Colour symbols refer to the grey coloured axes. 
TABLE 1. Legume protein used in this work

\begin{tabular}{|c|c|c|c|c|c|}
\hline Sample & Legumes & $\begin{array}{c}\text { Purity degree }^{1} \\
\left(\mathrm{~g} \mathrm{Kg}^{-1}\right)\end{array}$ & $\begin{array}{c}\mathbf{T}_{\mathrm{d}}{ }^{2} \\
\left({ }^{\circ} \mathrm{C}\right)\end{array}$ & $\begin{array}{c}\mathbf{T}_{\mathrm{g}}{ }^{3} \\
\left({ }^{\circ} \mathrm{C}\right)\end{array}$ & $\begin{array}{l}\mathbf{T}_{\mathrm{dg}}{ }^{4} \\
\left({ }^{\circ} \mathrm{C}\right)\end{array}$ \\
\hline Beans_44P & Borlotti beans & $443 \pm 2$ & - & - & 240.2 \\
\hline Beans_55P & Borlotti beans & $535 \pm 2$ & 211.5 & 148.9 & 245.2 \\
\hline Beans_75P & Borlotti beans & $752 \pm 1$ & 193.8 & 169.2 & 250.1 \\
\hline Chickpeas_70P & Chickpeas & $691 \pm 5$ & 204.7 & 172.5 & 287.6 \\
\hline Faba beans_88P & Faba beans & $879 \pm 4$ & 182.5 & 163.9 & 271.6 \\
\hline Lentils_45P & Lentils & $449 \pm 6$ & 199.5 & 155.6 & 255.6 \\
\hline Lentils_60P & Lentils & $587 \pm 22$ & - & - & 255.8 \\
\hline Lentils_75P & Lentils & $744 \pm 2$ & 183.4 & 169.1 & 260.4 \\
\hline Lentils_80P & Lentils & $796 \pm 11$ & - & - & 259.5 \\
\hline Peas_30P & Peas & $303 \pm 3$ & 202.8 & 92.4 & 178.2 \\
\hline Peas_40P & Peas & $419 \pm 11$ & 199.3 & 96.6 & 178.5 \\
\hline Peas_50P & Peas & $488 \pm 13$ & 201.3 & 105.8 & 196.6 \\
\hline Peas_68P & Peas & $685 \pm 3$ & 199.3 & 135.5 & 253.7 \\
\hline Peas_70P & Peas & $709 \pm 18$ & - & - & 258.4 \\
\hline Peas_77P & Peas & $778 \pm 3$ & 202.1 & 161.8 & 260.6 \\
\hline Peas_80P & Peas & $794 \pm 2$ & 199.8 & 143.7 & 263.0 \\
\hline
\end{tabular}


${ }^{1}$ Determined by Kjeldahl method analysis; ${ }^{2}$ Denaturation temperature at the maximum peak by DSC analysis; ${ }^{3}$ Glass transition temperature at the inflection point of the DSC plot; ${ }^{4}$ Degradation temperature at the onset of the second weight loss step in TGA analysis, the first step being assigned to moisture loss. 
TABLE 2. Band intensity in SDS page analysis for selected legume protein samples.

\begin{tabular}{|c|c|c|c|c|c|c|c|c|}
\hline \multirow{3}{*}{$\begin{array}{l}\text { Molecular weight } \\
\text { (kDa) }\end{array}$} & \multicolumn{8}{|c|}{ Protein samples } \\
\hline & $\begin{array}{c}\text { Peas_77 } \\
\text { P }\end{array}$ & $\begin{array}{c}\text { Peas_50 } \\
\text { P }\end{array}$ & $\begin{array}{c}\text { Peas_30 } \\
\text { P }\end{array}$ & $\begin{array}{c}\text { Lentils } \\
75 P\end{array}$ & $\begin{array}{c}\text { Beans_ } \\
\text { 75P }\end{array}$ & $\begin{array}{c}\text { Beans_ } \\
\text { 44P }\end{array}$ & $\begin{array}{l}\text { Chickp } \\
\text { eas_70P }\end{array}$ & $\begin{array}{c}\text { Faba } \\
\text { Beans } \\
\text { 88P }\end{array}$ \\
\hline & \multicolumn{8}{|c|}{ Band intensity (a.u.) } \\
\hline 13 & 1280 & & & & & & 775 & \\
\hline $\begin{array}{l}\text { 15-16 (double) } \\
{ }^{3} \text { vicilline }\end{array}$ & 1311 & 1460 & 1205 & 1101 & 1197 & & 1391 & 1478 \\
\hline 18 & & & & 1377 & 1083 & & & 1578 \\
\hline 21 & & 919 & & & 1182 & & & 1646 \\
\hline $\begin{array}{l}23-24 \\
\text { basic vicilline } \\
\text { fraction }\end{array}$ & 1281 & 1010 & 1678 & 1619 & & & & 1507 \\
\hline 30 & & & & & & & 1030 & \\
\hline 32 & 1755 & 2036 & 1894 & 1885 & 1818 & 2043 & 1529 & 2108 \\
\hline $37-38$ & 1145 & 1367 & 1521 & 1695 & & & 1367 & 1767 \\
\hline 40 & & & & 1756 & & & & 1609 \\
\hline $48-49$ & & 1576 & 1574 & 1684 & 1753 & 1324 & 1824 & 1709 \\
\hline 55 & & & & 1994 & & & & 1509 \\
\hline 58 & 1909 & & 1911 & & 2215 & & & \\
\hline $\begin{array}{l}60 \\
\text { legumine }\end{array}$ & & 1647 & & 1989 & & 1200 & 1866 & \\
\hline
\end{tabular}




\begin{tabular}{|l|l|l|l|l|l|l|l|l|}
\hline $\begin{array}{l}70 \\
\text { Convicilline }\end{array}$ & 1848 & 2295 & 2047 & 2042 & 1994 & 1819 & 1954 & 2100 \\
\hline
\end{tabular}




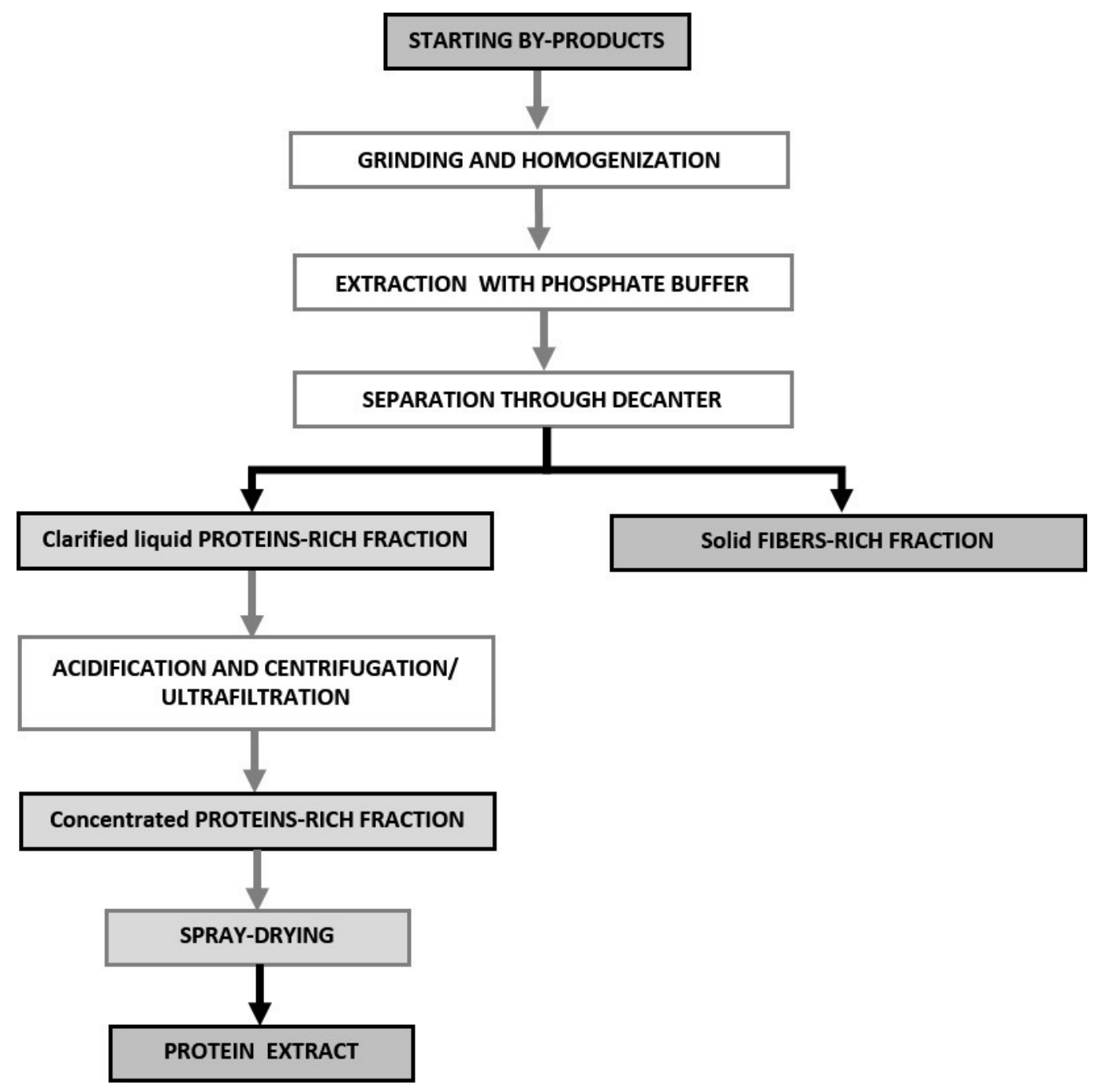

Figure 1.jpg

This article is protected by copyright. All rights reserved. 


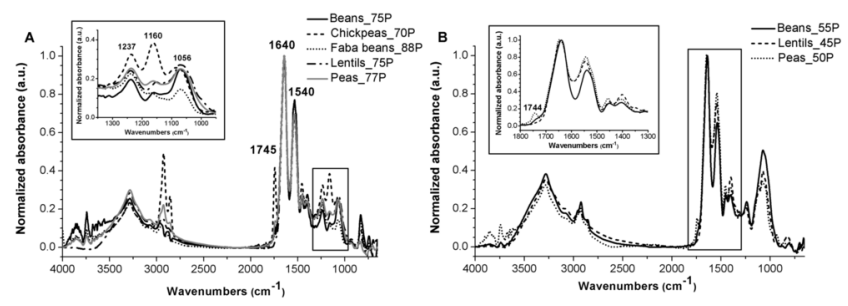

Figure 2rev.tif 


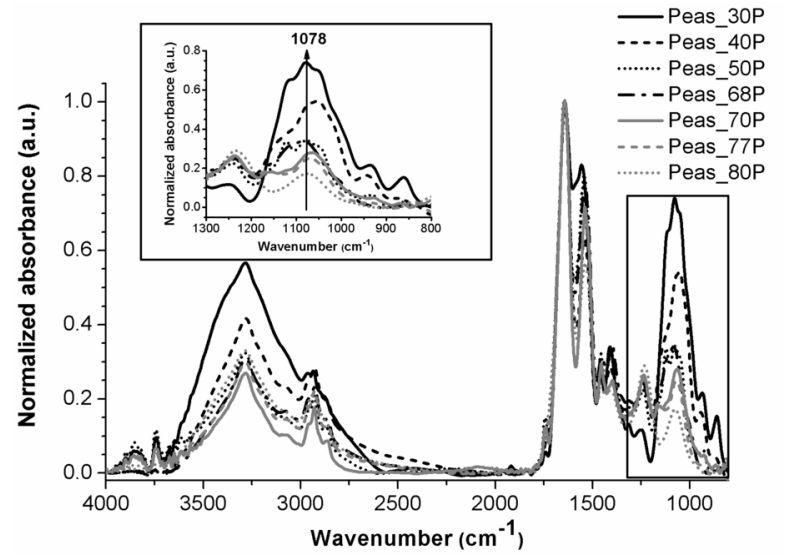

Figure 3BWrev.tif

This article is protected by copyright. All rights reserved. 


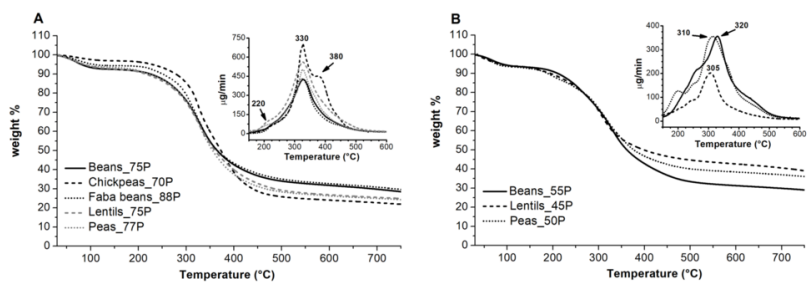

Figure 4rev.tif 

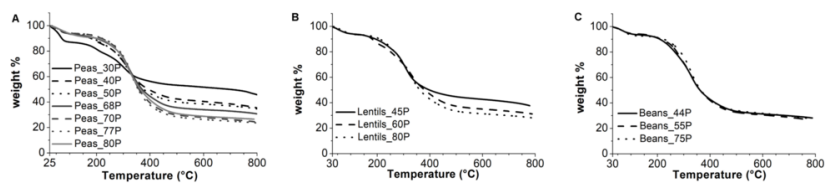

Figure 5rev.tif

This article is protected by copyright. All rights reserved. 


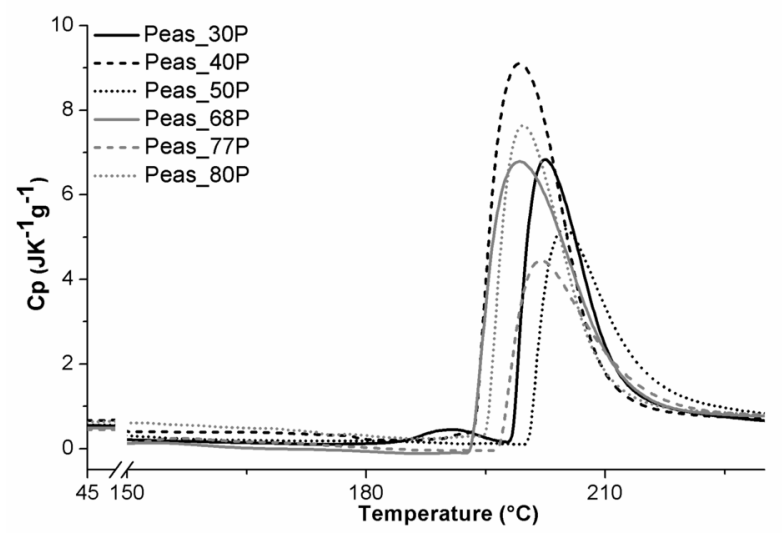

Figure 6.tif

This article is protected by copyright. All rights reserved. 


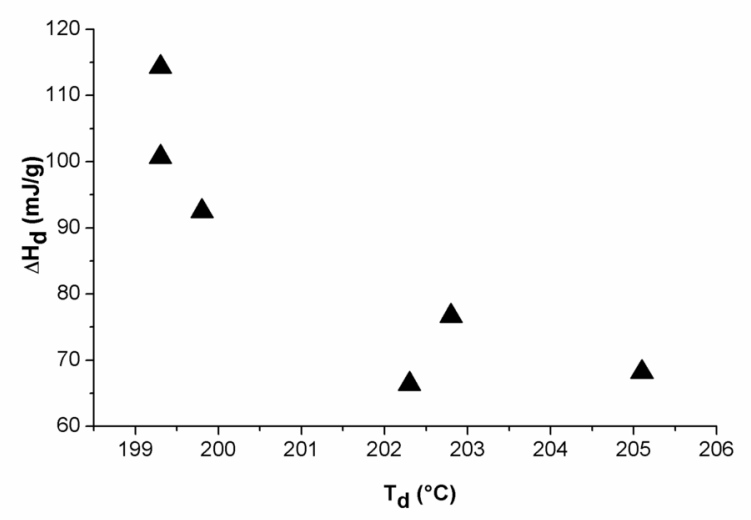

Figure 7.tif

This article is protected by copyright. All rights reserved. 


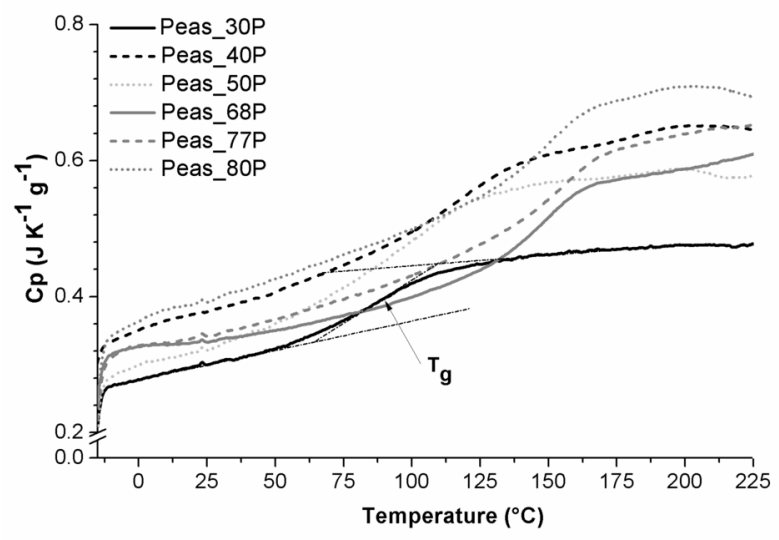

Figure 8.tif

This article is protected by copyright. All rights reserved. 


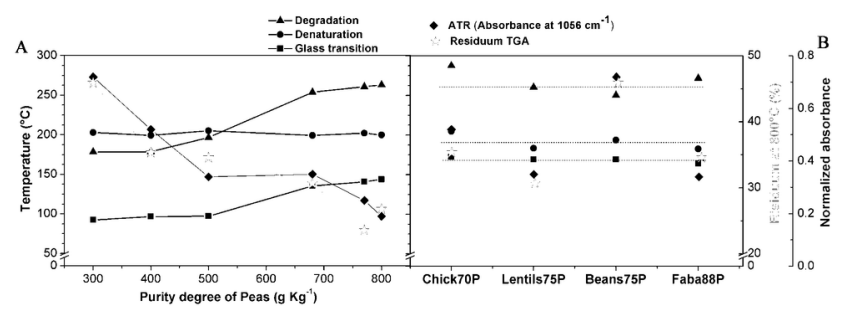

Figure 9rev.tif 